\title{
ANALISIS KINERJA KARYAWAN PT NOVELL PHARMACEUTICAL LABORATORIES DENGAN MENGGUNAKAN VARIABEL KOMPENSASI, LINGKUNGAN KERJA DAN MOTIVASI
}

\author{
YUGE AGUNG HELIAWAN \\ STIE AAS Surakarta \\ Email : ugtheniceboy@gmail.com
}

\begin{abstract}
ABSTRAK
Penelitian ini menguji dan menganalisis sumber daya manusia dalam perusahaan Studi tentang manajemen sumber daya manusia menunjukkan bagaimana seharusnya organisasi dapat mengembangkan, menggunakan, mengevaluasi dan memelihara dalam kuantitas dan kualitas yang tepat. melalui pemberian kompensasi yang layak, menciptakan lingkungan kerja yang kondusif, pemberian motivasi, pendidikan, dan pelatihan.

Penelitian tentang analisis faktor-faktor yang mempengaruhi kinerja karyawan perusahaan pada PT Novell Pharmaceutical Laboratories ini menggunakan Kompensasi dan Lingkungan Kerja sebagai variabel independen, Motivasi Kerja sebagai variabel intervening, dan Kinerja sebagai variabel dependen. Tujuan penelitian ini adalah untuk menganalisis pengaruh kompensasi dan lingkungan kerja terhadap kinerja karyawan melalui motivasi kerja sebagai variabel intervening. Sampel yang digunakan adalah karyawan PT Novell Pharmaceutical Laboratories sebanyak 35 responden dengan menggunakan metode sample random sampling. Analisis yang digunakan meliputi uji validitas, uji reliabilitas, uji asumsi klasik, uji model, analisis regresi linier dan intervening.

Hasil penelitian menyimpulkan bahwa berdasarkan uji-t yang dilakukan dan hasil analisis regresi linier 1 di atas dapat diketahui bahwa Kompensasi berpengaruh negative tidak signifikan terhadap motivasi sedangkan Lingkungan Kerja berpengaruh positif dan signifikan terhadap Motivasi dan pada hasil analisis regresi linier 2 diketahui bahwa Kompensasi berpengaruh positif signifikan terhadap Kinerja, Lingkungan Kerja berpengaruh positif tidak signifikan terhadap kinerja sedangkan Motivasi berpengaruh positif signifikan terhadap kinerja. Dan berdasarkan hasil dua analisis regresi linier di atas dapat dilakukan uji mediasi (intervening) sehingga diketahui bahwa varibel motivasi mampu menjadi variabel intervening oleh karena perhitungan standardized coeffients untuk pengaruh tidak langsung kompensasi dan lingkungan kerja terhadap kinerja melalui motivasi kerja lebih besar dibanding pengaruh secara langsung kompensasi dan lingkungan kerja terhadap kinerja.
\end{abstract}

Kata kunci : kompensasi, lingkungan kerja, motivasi, kinerja. 


\section{PENDAHULUAN}

Keefektifan setiap organisasi sangat dipengaruhi oleh perilaku manusianya. Manusia dan tenaganya merupakan sumber daya yang diperlukan bagi setiap organisasi. Tidak ada organisasi tanpa manusia dan setiap manusia dalam organisasi dituntut untuk memiliki prestasi yang tinggi, sekalipun setiap individu memiliki perilaku yang berbeda.

Sumber daya manusia dalam perusahaan PT Novell Pharmaceutical Laboratories adalah suatu aset yang tidak ternilai besarnya. Kemajuan Perusahaan PT Novell Pharmaceutical Laboratories mutlak ditentukan oleh baik tidaknya pengelolaan sumber daya manusia tersebut itu sendiri. Dalam suatu perusahaan, sumber daya manusia merupakan bagian yang utama dalam pemrosesan masukan (input) menjadi keluaran (output) yang dihasilkan perusahaan. Studi tentang manajemen sumber daya manusia menunjukkan bagaimana seharusnya organisasi dapat mengembangkan, menggunakan, mengevaluasi dan memelihara dalam kuantitas dan kualitas yang tepat.

Lingkungan kerja juga mempunyai peran besar dalam peningkatan kinerja pegawai, lingkungan kerja terdiri dari lingkungan fisik dan non fisik yang terkait langsung maupun tidak langsung dengan pegawai dan kinerja pegawai. Lingkungan kerja yang segar, nyaman dan memenuhi standar kebutuhan layak akan memberikan kontribusi terhadap kenyamanan pegawai dalam melaksanakan tugasnya. Lingkungan kerja nonfisik yang meliputi keramahan sikap para pegawai, sikap saling menghargai diantara sesama pegawai dan saling tolong menolong adalah syarat wajib untuk terus membina kualitas pemikiran pegawai yang akhirnya bisa meningkatkan kinerja secara berkelanjutan yang dipengaruhi oleh variabel motivasi, kompensasi dan lingkungan kerja.

\section{KAJIAN PUSTAKA \\ 1. Kinerja.}

Menurut Robbin (2001 :312)

Prestasi kerja atau kinerja akan tercapai apabila karyawan merasa bahwa apa yang dia peroleh dari hasil pekerjaannya telah memenuhi sesuatu yang dianggap menjadi harapan penting atau bahkan melebihi harapan yang diinginkan.

a. Faktor - faktor yang mempengaruhi kinerja.

Menurut Notoatmodjo (1998 : 31) mengemukakan factor yang mempengaruhi kinerja karyawan adalah :

(1) Kemampuan yang dapat dikembangkan ( Ability).

(2) Kemampuan yang sudah ditentukan atau terbatas (Capacity).

(3) Bantuan untuk terwujudnya kinerja ( Help ).

(4) Insentif material maupun non material ( Incentif ).

(5) Lingkungan tempat kerja karyawan (Environment).

(6) Pedoman dan uraian kerja ( Validity ).

(7) Umpan balik hasil kerja ( Evaluation ).

b. Penilaian kinerja.

Kinerja secara umum dipahami sebagai suatu catatan keluaran hasil pada fungsi jabatan atau seluruh aktifitas kerjanya dalam periode waktu tertentu. Secara singkat kinerja disebutkan sebagai suatu kesuksesan didalam melaksanakan suatu pekerjaan (As'ad, 2001:22).Tujuan penilaian kinerja adalah sebagai alat diagnostic dan proses penilai terhadap pengembangan individu, tim dan organisasi. Oleh karena kinerja 
merupakan suatu fungsi potensial, untuk mencapai dan mempertahankan kinerja diperlukan berbagai proses organisasi yang memungkinkan orang maupun program mewujudkan potensi mereka sepenuhnya. Kebutuhan untuk mencapai dan mempertahankan kinerja menentukan target organisasi.

\section{Motivasi Kerja}

Motif atau dalam bahasa asing disebut motive adalah sesuatu seperti kebutuhan atau keinginan yang mendorong atau mempengaruhi seseorang untuk melakukan gerak (Pamudji ; 2000: 127). Dengan demikian motivasi berarti suatu kondisi yang mendorong atau menjadi sebab seseorang melakukan suatu perbuatan atau kegiatan, yang berlangsung secara sadar (Nawawi ; 2008 : 87). Motivasi individu muncul dari dalam individu itu sendiri atau disebut motivasi intrinsic dan dapat pula berasal dari luar atau motivasi ekstrinsik. Para pimpinan harus mengetahui apa saja yang dapat memotivasi seseorang itu bersedia untuk bekerja dengan baik. Manajer atau pimpinan organisasi harus mampu untuk mengidentifikasi kebutuhan mana yang pada suatu saat dapat benarbenar menjadi motivator dan menggunakannya untuk meningkatkan kinerja bawahannya. Tetapi memang sangat sulit untuk menentukan alat motivasi yang paling tepat bagi masing-masing individu karena apa yang dibutuhkan tidak akan sama satu dengan yang lainnya. Di Amerika Serikat system upah dipakai pada $80 \%$ perusahaan organisasi untuk mendorong atau memotivasi pekerjanya. Dengan perkataan lain pemberian upah merupakan motivasi kerja yang penting dan mewujudkan pekerjaan yang produktif dan berkualitas (Nawawi, 2000 : 92).

\section{Kompensasi}

a. Pengertian Kompensasi

Pada dasarnya manusia bekerja juga ingin memeroleh uang untuk memenuhi kebutuhan hidupnya untuk itulah seorang karyawan mulai menghargai kerja keras dan semakin menunjukkan loyalitas terhadap perusahaan dan karena itulah perusahaan memberikan penghargaan terhadap prestasi kerja karyawan yaitu dengan jalan memberikan kompensasi. Salah satu cara manajemen untuk meningkatkan prestasi kerja, memotivasi dan meningkatkan kinerja para karyawan adalah melalui kompensasi (Mathis dan Jackson, 2000). Dessler dalam Jane Nelima, 2013 mendefinisikan:

"Compensation as all forms of payments or rewards given to employees which arise from employement."

b. Jenis-Jenis Kompensasi

Secara umum, ada dua jenis kompensasi dalam perusahaan, yakni:

i. Kompensasi Langsung

Sampai saat ini pengertian kompensasi langsung masih menggunakan istilah administrasi gaji dan upah, adapun pengertian dari kompensasi secara terpisah diungkapkan oleh Dessler (1998:89) kompensasi dengan pembayaran keuangan langsung dalam bentuk upah gaji, insentif, komisi dan bonus tetapi menurut Hasibuan (1995:133), kompensasi dibedakan menjadi dua macam yaitu: kompensasi langsung yang berupa gaji, upah, dan upah insentif, komisi dan bonus.

ii. Kompensasi Tak Langsung Selain kompensasi langsung, kompensasi tak langsung juga mempunyai peranan yang tak kalah pentingnya untuk meningkatkan kinerja karyawan. Menurut Dessler (1998:85) yaitu Semua pembayaran keuangan tak langsung yang diterima oleh seorang karyawan untuk melanjutkan pekerjaan dengan perusahaan. Pembagian 
kompensasi tak langsung dalam tunjangan keuangan, tunjangan hari raya, kesejahteraan karyawan jamsostek dan pelayanan kesehatan.

\section{Lingkungan Kerja}

Ahyari (2002 : 27) lingkungn kerja adalah suatu lingkungn dimana karyawan bekerja, sedangkan kondisi kerja merupakan kondisi dimana kayawan tersebut bekerja. Dengan demikian sebenarnya kondisi kerja termasuk salah satu unsur lingkungan kerja, dengan kata lain lingkungan kerja didalam suatu perusahaan bukan hanya terdiri dari kondisi kerja, dengan kata lain lingkungan kerja didalam suatu perusahaan bukan hanya terdiri dari kondisi kerja saja melainkan kondisi kerja ditambah dengan beberapa aspek lain yang membentuk lingkungan kerja. Berdasarkan pembatasan di atas, dapat ditafsirkan lingkungan kerja meliputi :

1) Kondisi bangunan dan ruang

2) Kondisi halaman dan kebun

3) Lokasi atau letak tempat (Perusahaan)

4) Fasilitas kerja

5) Fasilitas kebersihan

6) Tata tertib bagi karyawan

7) Kedisiplinan

8) Keamanan kerja

9) Kekeluargaan

\section{KERANGKA KONSEPTUAL}

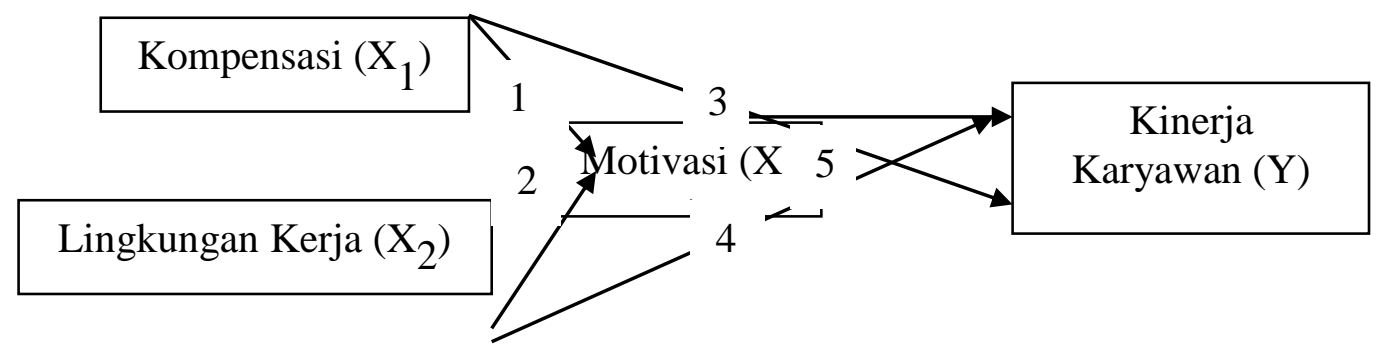

\section{HASIL PENELITIAN DAN PEMBAHASAN}

1. Uji Instrumen

Uji instrumen dilakukan terhadap indikator dari masing-masing variabel agar dapat diketahui tingkat kevalidan dan keandalan indikator sebagai alat ukur variabel. Uji instrumen terdiri dari uji validitas dan reliabilitas.

a. Uji Validitas

Uji validitas dilakukan untuk mengukur sah atau tidaknya indikator atau kuesioner dari masing-masing variabel. Pengujian dilakukan dengan membandingkan $r$ hitung dan $r$ tabel yang dianalisis dengan program SPSS dan outputnya bernama corrected item correlation dan didapatkan hasil dari 6 item pertanyaan semua valid dengan 2 Item pertanyaan tidak valid Validitas item pertanyaan untuk variabel Lingkungan Kerja $\left(\mathrm{X}_{2}\right)$

b. Uji Realibilitas

Uji reliabilitas digunakan untuk mengetahui apakah indikator atau kuesioner yang digunakan dapat dipercaya atau handal sebagai alat ukur variabel. Reliabilitas suatu indikator atau kuesioner dapat dilihat dari nilai cronbach's alpha $(\alpha)$, yaitu apabila nilai cronbach's alpha $(\alpha)$ lebih besar $(>) \quad 0,60$ maka indikator atau kuesioner adalah reliabel, sedangkan apabila nilai cronbach's alpha $(\alpha)$ lebih kecil (<) 0,60 maka indikator atau kuesioner tidak reliabel. Secara 
keseluruhan hasil uji reliabilitas dari hasil pengujian menunjukkan bahwa koefisien (r) alpha hitung seluruh variabel lebih besar dibandingkan dengan kriteria yang dipersyaratkan atau nilai kritis (rule of thumb) sebesar 0,6 sehingga dapat dikatakan bahwa butir-butir pertanyaan seluruh variabel dalam keadaan reliabel

\section{Uji Linieritas}

Uji linieritas digunakan untuk mengetahui status linier tidaknya suatu ditribusi sebuah data penelitian. Hasil yang diperoleh melalui uji linieritas akan menentukan teknik analisis regresi yang akan digunakan. Jika hasil uji linieritas merupakan data yang linier, maka digunakan regresi linier. Sebaliknya jika hasil uji linieritas merupakan data yang tidak linier maka analisis regresi yang dipakai juga non linier. Uji linieritas yang digunakan adalah uji Lagrange Multivariat. Estimasi dengan uji ini bertujuan untuk mendapatkan nilai $\mathrm{c}^{2}$ hitung atau ( $\mathrm{n} \times \mathrm{R}^{2}$ ). Dari hasil uji linieritas menunjukkan nilai $\mathrm{R}^{2}$ sebesar 0,001 dengan jumlah sampel 35 , besarnya nilai $\mathrm{c}^{2}$ hitung $=35 \mathrm{x}$ $0,001=0,35$ sedangkan nilai $\mathrm{c}^{2}$ tabel sebesar 43,78. Nilai $c^{2}$ hitung $<c^{2}$ tabel jadi dapat disimpulkan bahwa model yang benar adalah model linier.

\section{Uji Hipotesis}

Analisis ini digunakan untuk mengetahui pengaruh dari variabel bebas terhadap variabel terikat dengan menggunakan 2 persamaan.

\section{Uji t}

a. Pengaruh Kompensasi terhadap Motivasi

Hasil pengujian regresi 1 yang telah dilakukan menunjukkan untuk variabel kompensasi mempunyai nilai tidak signifikan $0,459>0,05$ artinya variabel kompensasi mempunyai pengaruh negatif tidak signifikan terhadap motivasi karyawan. Kesimpulan dari pengujian hipotesis 1 tidak terbukti.

b. Pengaruh Lingkungan Kerja terhadap Motivasi

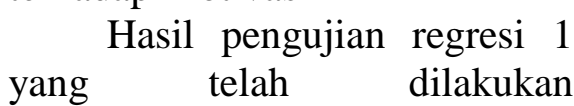
menunjukkan untuk variabel Lingkungan kerja mempunyai nilai signifikan $0,003<0,05$ artinya variabel Lingkungan kerja mempunyai pengaruh positif signifikan terhadap motivasi Karyawan. Kesimpulan dari pengujian hipotesis 2 terbukti.

c. Pengaruh Kompensasi terhadap Kinerja Karyawan

Hasil pengujian regersi 2 yang dilakukan menunjukkan untuk variabel kompensasi mempunyai nilai signifikan 0,00 $<0,05$ artinya variabel kompensasi mempunyai pengaruh positif signifikan terhadap kinerja karyawan. Kesimpulan dari pengujian ini hipotesis 3 terbukti.

d. Pengaruh Linkungan kerja terhadap Kinerja Karyawan

Hasil pengujian regersi 2 yang dilakukan menunjukkan untuk variabel kompensasi mempunyai nilai signifikan 0,127 $>0,05$ artinya variabel kompensasi mempunyai 
pengaruh positif tidak signifikan terhadap kinerja karyawan. Kesimpulan dari pengujian ini hipotesis 4 tidak terbukti.

e. Pengaruh Motivasi terhadap kinerja karyawan

Hasil pengujian regersi 2 yang dilakukan menunjukkan untuk variabel motivasi mempunyai nilai signifikan 0,025 $<0,05$ artinya variabel motivasi mempunyai pengaruh positif signifikan terhadap kinerja karyawan. Kesimpulan dari pengujian ini hipotesis 5 terbukti.

5. Uji F

Uji $F$ dilakukan untuk menguji hipotesis secara simultan atau bersama-sama antara variabel kompensasi lingkungan kerja dan motivasi terhadap kinerja. Hasil penghitungan $F$ hitung yang dilakukan dengan program SPSS

6. $\quad \mathrm{Uji} \mathrm{R}^{2}$

\begin{tabular}{lcr} 
Analisis & koefisien & determinasi \\
digunakan & untuk & mengetahui \\
besarnya & \multicolumn{2}{c}{ kontribusi/hubungan } \\
serempak & variabel & independen \\
terhadap & variabel & dependen. \\
Koefisien & determinasi & dinyatakan \\
dalam persentase. &
\end{tabular}

Analisis koefisien determinasi digunakan untuk mengetahui besarnya kontribusi/hubungan serempak variabel independen terhadap variabel dependen. Koefisien determinasi dinyatakan dalam persentase.
a. Koefisien
Determinasi

Persamaan 1

Uji $\mathrm{R}^{2}$ didapatkan hasil sebesar 0,264 atau $26,4 \%$ ini berarti bahwa motivasi kerja karyawan PT Novell Pharmaceutical Laboratories dijelaskan oleh variable kompensasi, lingkungan kerja sebesar $26,4 \%$ dan sisanya $73,6 \%$ dijelaskan variabel lain diluar model penelitian sebagai contoh kompetensi, gaya kepemimpinan dan sebagainya.

b. Koefisien

Determinasi

Persamaan 2

Uji $\mathrm{R}^{2}$ didapatkan hasil sebesar 0,669 atau $66,9 \%$ ini berarti kinerja karyawan PT. Novell Pharmaceutical Laboratories dijelaskan oleh variable kompensasi, lingkungan kerja dan motivasi kerja sebesar $66,9 \%$ dan sisanya $33,1 \%$ dijelaskan variable lain diluar model penelitian sebagai contoh gaya kepemimpinan, kompetensi, budaya kerja dan sebagainya.

c. Koefisien Determinasi / Varian Total

Nilai R square total sebesar 0,756 artinya kinerja karywan PT Novell Pharmaceutical Laboratories dijelaskan oleh Kompensasi dan Lingkungan Kerja dengan motivasi kerja sebagai variabel intervening sebesar $75,6 \%$ dan sisanya sebesar 24,4\% dijelaskan variabel lain di luar model penelitian sebagai contoh gaya kepemimpinan, budaya kerja, kompetensi dan sebagainya.

7. Analisis Koefisien Korelasi

Koefisien korelasi antar variabel independen dalam penelitian ini menggunakan koefisien korelasi Pearson yang diolah melalui SPSS, sedangkan untuk mengetahui kuat 
lemahnya hubungan antar variabel independen dengan variabel dependen, maka dapat dinyatakan dengan fungsi linier (paling tidak mendekati) dan diukur dengan suatu nilai yang disebut koefisien korelasi.

diketahui hubungan atau korelasi antar variabel sebagai berikut:

a) Korelasi antara Kompensasi dengan Motivasi menunjukkan angka korelasi sebesar 0,236** dengan nilai signifikansi sebesar $0,000<0,05$ sehingga dapat disimpulkan bahwa kompensasi mempunyai hubungan signifikan dan lemah dengan motivasi

b) Korelasi antara Lingkungan Kerja dengan motivasi menunjukkan angka korelasi sebesar $0,579 * *$ dengan nilai signifikansi sebesar $0,000<0,05$ sehingga dapat disimpulkan bahwa lingkungan kerja mempunyai hubungan signifikan dan cukup kuat dengan motivasi

c) Korelasi antara kompensasi dengan kinerja menunjukkan angka korelasi sebesar 0,713** dengn nilai signifikansi sebesar $0,000>0,05$ sehingga dapat disimpulkan bahwa kompensasi mempunyai hubungan signifikan dan kuat dengan motivasi.

d) Korelasi antara Linkungan kerja dengan kinerja menunjukkan angka korelasi sebesar 0,624** dengan nilai signifikansi sebesar $0,000<0,05$ sehingga dapat disimpulkan bahwa lingkungan kerja mempunyai hubungan signifikan dan kuat dengan kinerja.

e) Korelasi antara motivasi dengan kinerja menunjukkan angka korelasi sebesar $0,571 * *$ dengan nilai signifikansi sebesar $0,000<$ 0,05 sehingga dapat disimpulkan bahwa motivasi mempunyai hubungan signifikan dan cukup kuat dengan Kinerja

8. Pengaruh Langsung, Pengaruh Tidak Langsung dan Pengaruh Total

Tujuan analisis jalur adalah memperhitungkan pengaruh langsung dan tidak langsung, berdasarkan hasil analisis di atas dapat disusun kesimpulan analisis secara menyeluruh pada tabel berikut:

Tabel I

Hasil Pengaruh Langsung, Pengaruh Tidak Langsung dan Pengaruh Total

\begin{tabular}{|l|l|c|l|l|}
\hline No & \multicolumn{1}{|c|}{ Antar Variabel } & $\begin{array}{c}\text { Pengaruh } \\
\text { Langsung }\end{array}$ & $\begin{array}{c}\text { Pengaruh Tak } \\
\text { Langsung }\end{array}$ & Total Pengaruh \\
\hline 1 & Kompensasi $\rightarrow$ Kinerja & $0,571^{* *}$ & & \\
2 & Lingkungan Kerja $\rightarrow$ Kinerja & 0,212 & \\
3 & Motivasi $\rightarrow$ Kinerja & $0,283^{* *}$ & & \\
\hline 1 & Kompensasi $\rightarrow$ Motivasi kerja $\rightarrow$ & & $-0,129 \times 0,283^{* *}=$ & $0,571+0,0365$ \\
& Kinerja & & $-0,0365$ \\
& & $0,562^{* *} \times 0,283^{* *}$ & 0,6075 \\
& Lingkungan Kerja $\rightarrow$ motivasi & & $0,159^{* *)}$ & $\begin{array}{l}0,212+0,159= \\
0,371 * *)\end{array}$ \\
\hline
\end{tabular}




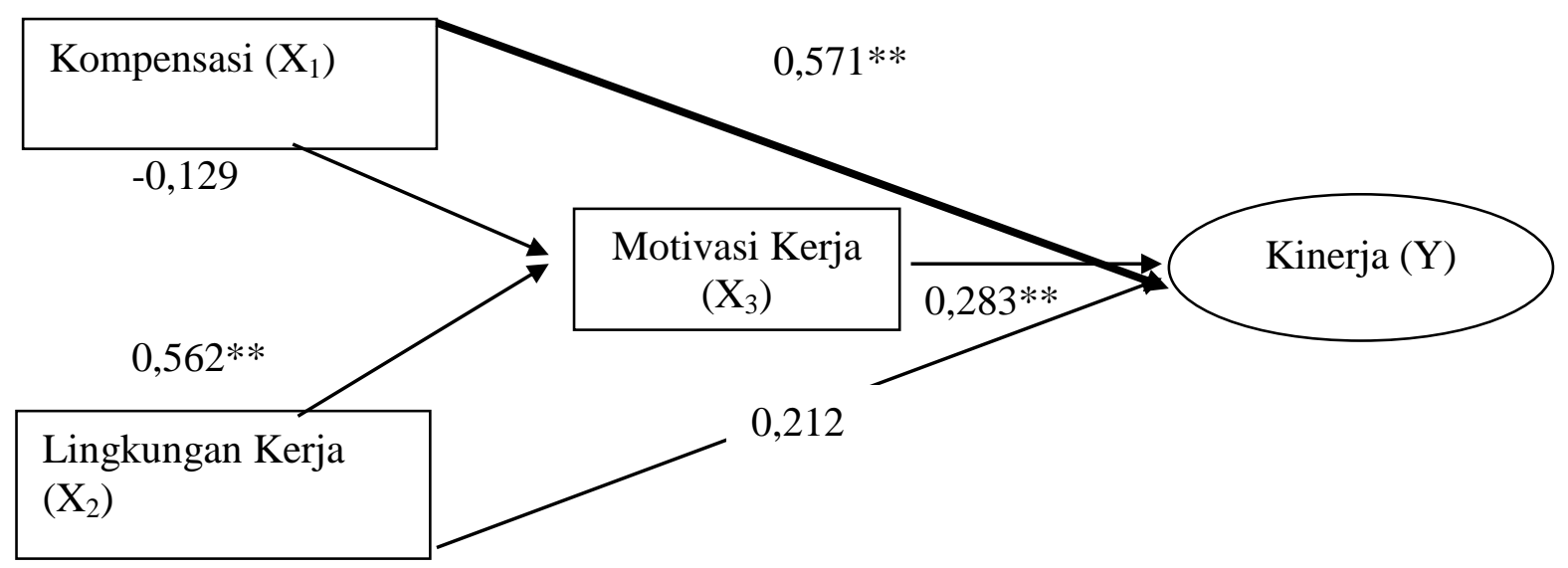

Gambar IV. 1 Hasil Pengaruh Langsung dan Tidak Langsung

1) Pengaruh langsung

Pengaruh langsung adalah pengaruh dari satu variabel independen menuju variabel dependen tanpa melalui variabel dependen lainnya.

a) Kompensasi terhadap Kinerja Karyawan $\left(\mathrm{X}_{1}\right.$ ke $\left.\mathrm{Y}\right)$

Berdasarkan gambar IV.1 diketahui Kompensasi berpengaruh positif dan signifikan terhadap kinerja karyawan PT Novell Pharmaceutical Laboratories dengan koefisien sebesar $0,571\left(\mathrm{P}_{1}\right)$.

b) Lingkungan Kerja terhadap Kinerja Karyawan $\left(\mathrm{X}_{2}\right.$ ke $\left.\mathrm{Y}\right)$

Berdasarkan gambar

IV.1 diketahui Lingkungan kerja berpengaruh positif dan tidak signifikan terhadap kinerja karyawan PT Novell Pharmaceutical Laboratories dengan koefisien sebesar $0,212\left(\mathrm{P}_{2}\right)$.

c) Pengaruh Motivasi kerja terhadap Kinerja Karyawan $\left(\mathrm{X}_{3}\right.$ ke $\left.\mathrm{Y}\right)$

Berdasarkan gambar IV.1 diketahui motivasi kerja berpengaruh positif dan signifikan terhadap kinerja PT Novell Pharmaceutical Laboratories dengan koefisien sebesar 0,283 $\left(\mathrm{P}_{5}\right)$.

2) Pengaruh tidak langsung

Pengaruh tidak langsung adalah hubungan antara variabel independen yang mempengaruhi variabel dependen melalui mediasi 
variabel lain yang disebut variabel intervening (intermediary).

a) Pengaruh Kompensasi terhadap Kinerja karyawan melalui Motivasi Kerja $\left(\mathrm{X}_{1}\right.$ ke $\mathrm{X}_{3}$ dan $\mathrm{X}_{3}$ ke $\mathrm{Y}$ ).

Berdasarkan gambar IV.1 diketahui Kompensasi berpengaruh negatif terhadap motivasi kerja serta motivasi kerja berpengaruh positif dan signifikan terhadap Kinerja Karyawan dengan koefisien sebesar $-0,129 \times 0,283 * *=$ 0,0365

b) Pengaruh Lingkungan Kerja terhadap Kinerja Karyawan melalui Motivasi kerja $\left(\mathrm{X}_{2}\right.$ ke $\mathrm{X}_{3}$ dan $\mathrm{X}_{3}$ ke $\mathrm{Y}$ ).

Berdasarkan Gambar IV.1 diketahui Lingkungan Kerja berpengaruh positif dan signifikan terhadap motivasi kerja serta motivasi kerja berpengaruh positif dan signifikan terhadap Kinerja Karyawan dengan koefisien sebesar $0,562 * * \times 0,283 * *=$ $0,159 * *)$

3) Pengaruh total (total effect)

a) Pengaruh Kompensasi terhadap Kinerja Karyawan melalui Motivasi Kerja Karyawan Berdasarkan hasil pengujian regresi linier berganda persamaan pertama dan kedua menunjukkan pengaruh total dari pengaruh langsung dan tidak langsung yaitu $0,571+0,0365=$ 0,6075 . Hal ini menunjukkan bahwa pengaruh keseluruhan dari kompensasi terhadap kinerja melalui motivasi kerja sebesar 0,6075. b) Pengaruh Lingkungan Kerja terhadap Kinerja Karyawan melalui Motivasi kerja.

Berdasarkan hasil pengujian regresi linier berganda persamaan dan kedua menunjukkan pengaruh total dari pengaruh langsung dan tidak langsung yaitu $0,212+0,159=0,371$. Hasil ini menunjukkan bahwa pengaruh keseluruhan dari Lingkungan kerja terhadap Kinerja melalui motivasi kerja sebesar 0,371 .

4) Kesimpulan analisis Jalur.

a) Pengaruh langsung Kompensasi terhadap Kinerja Karyawan merupakan pengaruh yang paling dominan.dengan koefisien sebesar 0,571 $\left(\mathrm{P}_{3}\right)$.

b) Pengaruh Lingkungan Kerja terhadap Kinerja Karyawan melalui Motivasi kerja diketahui Lingkungan Kerja berpengaruh positif dan signifikan terhadap motivasi kerja serta motivasi kerja berpengaruh positif dan signifikan terhadap Kinerja Karyawan dengan koefisien sebesar $0,562 * *$ x $0,283 * *=$ $0,159 * *) .\left(\mathrm{P}_{2} \quad \mathrm{X} \quad \mathrm{P}_{5}\right)$, merupakan alternatif jalur efektif yang ke dua.

c) Pengaruh Lingkungan kerja terhadap kinerja karyawan PT Novell Pharmaceutical Laboratories positif dan tidak signifikan.

\section{PEMBAHASAN}




Berdasarkan hasil pengujian
hipotesis tersebut, maka dapat
diimplementasikan hal-hal sebagai
berikut:

1. Pengaruh Kompensasi terhadap Motivasi dan Kinerja

Pengaruh langsung

kompensasi positif dan tidak signifikan terhadap kinerja karyawan dengan nilai sebesar 0,571. Pengaruh tidak langsung kompensasi melalui variabel motivasi mempunyai pengaruh negatif dan tidak signifikan 0,0365 .

Temuan ini tidak mendukung hasil penelitian I Made Yusa Dharmawan (2011), Budi Darma Putra (2012), Ginanjar Sigit Nursasongko (2012), Nadya Wahyunigtyas (2013), Nadya Wahyunigtyas (2013), Nunung Ristiana (2012), menemukan hasil dalam penelitiannya bahwa kompensasi berpengaruh signifikan terhadap kinerja karyawan

Hal ini menunjukkan bahwa penggunaan variable intervening motivasi kerja dalam rangka peningkatan kinerja karyawan PT Novell Pharmaceutical Laboratories Branch Solo untuk variabel kompensasi tidak efektif, karena pengaruh tidak langsung variabel kompensasi terhadap kinerja melalui motivasi kerja menghasilkan pengaruh yang kecil daripada pengaruh langsung.

Hasil penelitian ini mendukung temuan penelitian Nadya Wahyunigtyas (2013), Nunung Ristiana (2012), Ginanjar Sigit Nursasongko (2012), Budi Darma Putra (2012), menemukan bahwa kompensasi berpengaruh signifikan terhadap kinerja Dari uji validitas didapatkan skor tertinggi terletak pada butir $\mathrm{X}_{1 \_} 6, \mathrm{X}_{1 \_} 8, \mathrm{X}_{1 \_} 1$ untuk itu rekomendasi atau langkah yang dapat dilakukan secara kongkrit adalah:

a. Pimpinan perlu meningkatkan fasilitas kerja diluar gaji pokok yang diterima karyawan seperti adanya program asuransi, tunjangan dan program lainnya yang dapat meningkatkan kesejahteraan karyawan.

b. Pimpinan perlu membuat program-program khusus yang ditujukan kepada karyawan guna meningkatkan kenyamanan dan kesejahteraan karyawan sehingga dapat memberikan motivasi serta meningkatkan kinerja karyawan.

c. Pimpinan perlu meningkatkan gaji karyawan agar diberikan sesuai kesepakatan dan gaji tetap diberikan kepada karyawan yang ijin (tetap diberikan meskipun ijin kerja).

2. Pengaruh Lingkungan Kerja terhadap Motivasi dan Kinerja

Pengaruh langsung variabel lingkungan kerja 0,212 positif dan tidak signifikan terhadap kinerja. Pengaruh tidak langsung melalui variabel motivasi mempunyai pengaruh positif dan signifikan 0,159. Penggunaan variable intervening motivasi kerja dalam rangka meningkatkan kinerja, untuk variabel lingkungan kerja lebih tepat dan efektif, karena pengaruh tidak langsung lingkungan kerja terhadap kinerja 
menghasilkan nilai yang lebih besar daripada pengaruh langsung. Hasil penelitian ini mendukung temuan penelitian Sri Hartati (2010) yang menemukan bahwa Lingkungan kerja berpengaruh positif dan signifikan terhadap motivasi, serta hasil penelitian Nunung Ristiana (2012), Ismaryati (2002) menemukan hasil dalam penelitiannya, bahwa motivasi berpengaruh signifikan terhadap kinerja

Dari uji validitas lingkungan kerja didapatkan skor tertinggi terletak pada butir $\mathrm{X}_{2} 6$, $\mathrm{X}_{2} \_2, \quad \mathrm{X}_{2}$ 7. Untuk itu rekomendasi atau langkah yang dapat dilakukan secara kongkrit untuk meningkatkan lingkungan kerja adalah:
a. Pimpinan
perlu
memperhatikan
tingkat
kenyamanan lingkungan kerja baik fisik maupun non fisik yang sehingga memberikan suasana menyenangkan bagi para karyawannya.
b. Pimpinan perlu memperhatikan dan meningkatkan fasilitas kerja yang tersedia agar tetap memadai dan mendukung efektivitas proses pekerjaan.
c. Pimpinan perlu meningkatkan ruang kerja yang nyaman, tidak sehingga mendukung penyelesaian pekerjaan.

Selanjutnya untuk mendorong peninggkatan motivasi yang berdampak terhadap kinerja dilakukan dengan melihat uji validitas motivasi didapatkan skor tertinggi terletak pada butir $\mathrm{X}_{3-} 8$, $\mathrm{X}_{3 \_} 2, \quad \mathrm{X}_{3 \_} 4$,. Untuk itu rekomendasi atau langkah yang dapat dilakukan secara kongkrit untuk meningkatkan motivasi adalah:
a. Memberikan kompensasi dalam bekerja
b. Memberikan kompensasi diberikan tepat pada waktunya
c. Memberikan
motivasi/dukungan dan
kenyamanan dalam
kekeluargaan/persabatan antar karyawan membuat

\section{KESIMPULAN DAN SARAN}

\section{Kesimpulan}

Berdasarkan hasil analisis data pengujian hipotesis yang telah dilakukan maka dapat ditarik kesimpulan sebagai berikut :

1. Uji t pada persamaan Pertama dapat disimpulkan bahwa Variabel Kompensasi berpengaruh negative sedangkan Lingkungan Kerja berpengaruh positif dan signifikan terhadap Motivasi kerja. Hal ini dapat dilihat dari nilai signifikan dari Variabel Kompesasi ke variabel Motivasi 0,459>0,05 sedangkan pada Variabel Lingkungan kerja kevariabel motivasi $0,03<0,05$.

2. Dari Uji t pada persamaan kedua dapat disimpulkan bahwa variabel Motivasi Kerja berpengaruh positif dan signifikan terhadap Kinerja. Hal ini dapat dilihat dari nilai signifikansi masing-masing variabel $<\quad 0,05$. Sedangkan variabel Kompensasi berpengaruh positif dan signifikan terhadap Kinerja, dan Lingkungan Kerja berpengaruh positif dan signifikan terhadap Kinerja Karyawan PT. Novell Pharmaceutical Laboratories.

3. Hasil uji secara serempak (Uji F) pada persamaan kedua diketahui 
besarnya nilai $\mathrm{F}=20,908$ signifikansi $0,000<0,05$. Sehingga dapat disimpulkan secara bersamasama variabel bebas (Kompensasi dan Lingkungan kerja) mempengaruhi Kinerja karyawan PT Novell Pharmaceutical Laboratories

4. Nilai R square total sebesar 0,756 artinya kinerja karywan PT Novell Pharmaceutical Laboratories dijelaskan oleh Kompensasi dan Lingkungan Kerja dengan motivasi kerja sebagai variabel intervening sebesar $75,6 \%$ dan sisanya sebesar $24,4 \%$ dijelaskan variabel lain di luar model penelitian sebagai contoh gaya kepemimpinan, budaya kerja, kompetensi dan sebagainya.

5. Hasil analisis jalur.

a. Pengaruh langsung Kompensasi terhadap Kinerja Karyawan merupakan pengaruh yang paling dominan.

b. Pengaruh Lingkungan Kerja terhadap Kinerja Karyawan melalui Motivasi kerja diketahui Lingkungan Kerja berpengaruh positif dan signifikan terhadap motivasi kerja serta motivasi kerja berpengaruh positif dan signifikan terhadap Kinerja Karyawan, merupakan alternatif jalur efektif yang ke dua.

c. Pengaruh Lingkungan kerja terhadap kinerja karyawan PT Novell Pharmaceutical Laboratories positif dan tidak signifikan.

\section{Saran dan Rekomendasi}

Berdasarkan hasil penelitian disarankan hal-hal sebagai berikut :
1. Faktor kompensasi karyawan PT Novell Pharmaceutical Laboratories perlu ditingkatkan, termasuk pemberian bonus dan kesesuaian gaji dengan kebutuhan karyawan dan adanya program-program khusus karyawan yang dapat meningkatkan kesejahteraan karyawan, karena dengan kompensasi yang sesuai akan memberikan motivasi kerja yang sangat kuat sehingga kinerja akan meningkat.

2. Faktor lingkungan kerja baik lingkungan fisik maupun non fisik perlu ditingkatkan kenyamanannya. Secara fisik, seperti fasilitas sarana-prasarana yang ada perlu dijaga kebersihan dan dilakukan perawatan agar tidak rusak. Termasuk hubungan antar rekan kerja juga dijaga agar tetap kondusif. Sekalipun dari hasil peneltian menunjukkan bahwa lingkungan kerja tidak berpengaruh langsung terhadap kinerja karyawan, tetapi lingkungan kerja sangat mempengaruhi motivasi kerja karyawan yang kemudian melalui motivasi akan meningkatkan kinerja karyawan PT Novell Pharmaceutical Laboratories

3. Dalam rangka meningkatkan Kinerja karyawan PT Novell Pharmaceutical Laboratories sebaiknya menggunakan variabel motivasi kerja. variabel kompensasi dan lingkungan kerja ditujukan untuk meningkatkan motivasi kerja. 


\section{DAFTAR PUSTAKA}

Ajala Emanuel Majekodunmi. 2012. The Influence of Workplace Environment on Workers'Welfare, Performance and Productivity. The African Symposium Volume 12, No. 1, page 141, June 2012.

Arikunto, S., 2002. Prosedur Penelitian: Suatu Pendekatan Praktek. Edisi Revisi V, Jakarta : Rineka Cipta.

Dharmawan, I Made Yusa. 2011. Pengaruh Kompensasi dan Lingkungan Kerja Non Fisik Terhadap Disiplin dan Kinerja Karyawan Hotel NIKKI Denpasar. eprints.unud.ac.id. Denpasar: Universitas Udayana

Dito, Anoki Herdian. 2010. Pengaruh Kompensasi Terhadap Kinerja Karyawan PT. Slamet Langgeng Purbalingga dengan Motivasi Sebagai Variabel Intervening.

eprints.undip.ac.id. Semarang: Universitas Diponegoro

Ghozali, Imam. 2005. Aplikasi Analisis Multivariate dengan SPSS. Semarang : Badan Penerbit Undip Semarang.

Handoko, T, Hani. 2001. Manajemen Personalia dan Sumber Daya Manusia. Yogyakarta : BPFE

Hani, Handoko, 2005. Manajemen Personalia dan Sumber Daya Manusia. UGM, Yogyakarta: BPFE.

Hasibuan 2007. Manajemen Sumber Daya Manusia, cetakan kesembilan, Jakarta : PT Bumi Aksara

Leblebici, Demet. 2012. Impact of Workplace Quality on Employee's Productivity: Case
Study of A Bank in Turkey. Journal of Business, Economic \& Finance, ISSN: 2146-7943, Volume 1, Issue 1, 2012.

Lewa, Eka Idham K. dan Subowo. 2005. Pengaruh Kepemimpinan, Lingkungan Kerja Fisik, dan Kompensasi terhadap Kinerja Karyawan di PT. Pertamina Daerah operasi Hulu Jawa Bagian Barat, Cirebon. Halaman 129-140, Sinergi

Mathis dan Jackson. 2000. Manajemen Sumber Daya Manusia, Jakarta : Salemba Empat.

Mangku Negara, A.A.Anwar Prabu. 2006. Evaluasi Kinerja SDM. Cetakan kedua. Bandung : PT. Refika Aditama.

Nitisemito, Alex S. 2002. Manajemen Personalia. Cetakan Kesembilan. Edisi Keempat, Jakarta: Ghalia Indonesia.

Nursasongko, Ginanjar Sigit. 2012. Analisis Pengaruh Kepemimpinan, Lingkungan Kerja dan Kompensasi Terhadap Kinerja Pegawai (Studi pada Badan Kepegawaian Daerah Kabupaten Pemalang). eprints.undip.ac.id. Semarang: Universitas Diponegoro

Pramudyo, Anung. 2010. Analisis Faktor-faktor yang Mempengaruhi Kinerja Dosen Negeri Dipekerjakan Pada Kopertis Wilayah $V$ Yogyakarta. Volume 1, Nomor 1, JBTI: Yogyakarta.

$$
\begin{array}{r}
\text { Rahmawanti, Nela Pima, Bambang } \\
\text { Swasto dan Arik Prasetyo. } \\
\text { 2014. Pengaruh Lingkungan } \\
\text { Kerja Terhadap Kinerja } \\
\text { Karyawan (Studi pada } \\
\text { Karyawan Kantor Pelayanan } \\
\text { Pajak Pratama Malang Utara). }
\end{array}
$$


Jurnal Administrasi Bisnis (JAB)| Vol. 8 No. 2 Maret 2014.

Rivai, Veithzal. 2005. Manajemen Sumber Daya Manusia Untuk Perusahaan dari Teori ke Praktek. Cetakan pertama. Jakarta : PT. Raja Grafindo Persada.

Rivai, Veithzal. 2006. Manajemen Sumber Daya Manusia untuk Perusahaan : Dari Teori ke Praktik. Edisi Pertama. Jakarta: Penerbit PT. Raja Grafindo Persada.

Robbins, Stephen P. 2002. Perilaku Organisasi. Jakarta: Erlangga.

Sedarmayanti. 2007. Sumber Daya Manusia dan Produktivitas Kerja. Bandung : Mandar Maju.

Siagian, Sondang P. 2002. Kiat Meningkatkan Produktivitas Kerja. Jakarta : Rineka Cipta

Sopiah. 2008. Perilaku Organisasional. Yogyakarta : Andi Offset
Sugiyono, 2006. Metode Penelitian Bisnis. Cetakan Kedelapan. Bandung : CV. Alfabeta

Sugiyono. 2002. Metode Penelitian Bisnis. Bandung: Alfabeta.

Sumarsono, Sonny. 2004. Metode Riset Sumber Daya Manusia. Graha ilmu: Yogyakarta.

Wahyunigtyas, Nadya. 2013. Pengaruh Lingkungan Kerja dan Kepuasan Kompensasi terhadap Kinerja Karyawan (Studi pada Bank Jateng Cabang Koordinato Semarang). eprints.undip.ac.id. Semarang: Universitas Diponegoro.

Wekesa, Jane Nelima \& Silas Nyaroo, M.A. 2013. Effect of Compensation on Performance of Public Secondary School Teachers in Eldoret Municipality Kenya. International Journal of Scientific and Reseacrh Publications, Volume 3, Issue 6, ISSN 2250-3153, June 2013. 